\title{
EFFECT OF KIND OF DEFORMATION ON YOUNG'S MODULUS, DAMAGE PARAMETER, TEXTURE AND STRUCTURE OF ALLOY Mg - 5\% Li (wt)
}

\author{
DValentin Usova*, (D) Heinz-Günter Brokmeier ${ }^{b, e}$, Dataliia Shkatulyak ${ }^{c}$, \\ (D)Elena Savchuk ${ }^{\mathrm{d}}$, Norbert Schell \\ ${ }^{a}$ South Ukrainian National Pedagogical University named after K. D. Ushinsky, Department of Technological and Professional \\ Education, Staroportofrankovskaya Str. 26, 65020, Odessa, Ukraine, \\ ${ }^{b}$ Institute for Materials Science and Engineering - Department of TEXMAT - University of Technology Clausthal \\ Agricolastrasse, 6, D-38678, Clausthal-Zellerfeld, Germany \\ 'South Ukrainian National Pedagogical University named after K. D. Ushinsky, Department of Physics \\ Staroportofrankovskaya Str. 26, 65020, Odessa, Ukraine \\ "National University "Odessa Maritime Academy", Department of Physics \\ Didrichson's street, 8, 65000 Odessa, Ukraine \\ ${ }^{e}$ German Engineering Materials Science Centre (GEMS), Helmholtz-Zentrum Geesthacht \\ Max-Planck-Str. 1, D-21502 Geesthacht, Germany \\ *Corresponding Author: valentinusov67@gmail.com
}

Received December 14, 2019; revised December 24, 2019; revised January 13, 2020; accepted January 21, 2020

Effect of deformation by extrusion, rolling after extrusion (in combination with annealing and changing the rolling direction), and subsequent alternating bending $(\mathrm{AB})$ with the number of cycles $0.5,1,3$, and 5 on the elastic modulus $(E)$, damage accumulation parameter (damage parameter $\omega$ ), crystallographic texture, and substructure parameters of the binary $\mathrm{Mg}-5 \% \mathrm{Li}$ alloy have been studied. The damage parameter $(0 \leq \omega \leq 1)$, which is interpreted as the relative reduction in the effective load-bearing cross-sectional area due to damage accumulation, was found by the change in the elastic modulus after various above types of deformation. At this, we used to compare equivalent deformation and equivalent elastic energy models. The substructure parameters (crystalline domains sizes $\mathrm{D}$, lattice distortion $\varepsilon$, dislocation density $\rho$ ) were estimated by analyzing the physical broadening of the lines diffraction on the crystal lattice of studied alloy of the penetrating hard X-ray synchrotron radiation. It was found that in the studied alloy, sheet forms a texture, at which the hexagonal prism axis is $90^{\circ}$ deviated from the normal direction (ND) to the sheet up to transverse direction (TD) after extrusion of the ingot at $350^{\circ} \mathrm{C}$ in combination with its further rolling in the direction of extrusion axis (rolling direction RD) to a thickness of $4.5 \mathrm{~mm}$ and annealing at $350^{\circ} \mathrm{C}$ after each pass. At this the crystallographic directions $\langle\mathbf{1 1} \overline{\mathbf{2}} \mathbf{0}\rangle$ and $\langle\mathbf{1 0} \overline{\mathbf{1}} \mathbf{0}\rangle$ coincide with RD. The texture, at which the hexagonal prism axis is deviated from ND to TD by angles ranging from 15 to $70^{\circ}$ (unlike from texture of basal type of the pure magnesium) is formed after further rolling of studied alloy to a thickness of $1 \mathrm{~mm}$ with the changing of the RD on $90^{\circ}$ in combination with annealing at $350^{\circ} \mathrm{C}$ after each pass. The crystallographic direction $\langle\mathbf{2 1 3} 1\rangle$ coincides with RD. The anisotropy of above mentioned characteristics was found. Correlation and regression analysis showed that the anisotropy and the values of E, D, $\varepsilon$, and $\rho$, are decreased, and the values of $\omega$ are increased with an increase of alternating bend cycles' number. It is shown that changes in the above characteristics are mainly due to the crystallographic texture formed during thermomechanical processing and subsequent alternating bending of $\mathrm{Mg}-5 \% \mathrm{Li}$ alloy sheets, which is confirmed by data of correlation and regression analysis.

KEYWORDS: extrusion, rolling, alternating bending, texture, anisotropy, Young's modulus, damage parameter, substructure.

Magnesium and its alloys have recently attracted scientific and practical interest due to the increased demand for weight loss in a number of industries such as automotive, aerospace. Low density and high specific strength are the basis for such interest [1]. However, pure magnesium and its usual alloys with aluminum and zinc of the AZ31 type exhibit insufficient formability during stamping and deep drawing [2]. It is known that magnesium shows a pronounced anisotropy of mechanical properties after deformation. Anisotropy of the mechanical properties arises mainly due to the pronounced texture, which develops during plastic deformation, which is typical for metals with a hexagonal crystal structure. Moreover, in the production of sheet material, texture can, in principle, affect the production process and the resulting mechanical properties. The deformation behavior of hexagonal metals as a whole significantly complicates the variety of possible deformation mechanisms, such as basic, prismatic, pyramidal sliding and a number of twinning modes. In addition, activation of deformation mechanisms depends on the $c / a$ ratio [3]. Thus, there is a need for the development of new magnesium alloys with high corrosion resistance and good mechanical properties. It was shown that alloying magnesium with a small amount of lithium can significantly increase the ductility and corrosion resistance even in an alloy with a hexagonal lattice [4].

Usually, sheet and rolled metal would be straightened by roller straightening machines before use in order to reduce residual stresses and increase flatness [5]. In the process of straightening, sheet metal is subjected to alternating tensile deformation of the convex side and compression on the concave side of the sheet due to alternating bending (AB). Significant changes in the microstructure and texture occur during the AB process, despite a slight deformation [6]. The crystallographic texture formation in $\mathrm{Mg}-5 \% \mathrm{Li}$ (wt) alloy sheets was studied in [6], after the ingot extrusion and subsequent rolling at a change in direction, as well as the effect of the subsequent $\mathrm{AB}$ on the microstructure, texture and anisotropy of mechanical properties. It was found that the intensity and scattering of the texture depend on $\mathrm{AB}$ 
cycles number. The most significant changes in texture were observed after $3 \ldots .5$ cycles of AB. Texture changes affected the anisotropy of mechanical properties. Regular changes in the anisotropy of both mechanical properties and the microstructure, represented by equiaxed grains containing twins, occur during alternating bending.

At the same time, it is not investigated the tendency to destruction of $\mathrm{Mg}-5 \% \mathrm{Li}$ alloy sheets obtained as a result of deformation by extrusion and subsequent rolling with a change in direction and further alternating bending. As was mentioned above, the alternating bending is used to increase flatness and reduce of residual stresses in the sheet metal before its use. In this case, sub- and microdefects accumulate in the metal during deformation: point (vacancies and interstitial atoms), linear (dislocations), surface (submicrocracks), bulk (micropores). Association of these defects during the increase in deformation leads to formation of microcracks, which are combined into the main crack that can lead to failure $[7,8]$.

The damages accumulation concept of the continuum mechanics turned out to be promising for describing the macroscopic behavior of a material during deformation. To characterize the accumulation of damage, the so-called damage parameter $\omega$ is used, which was proposed already in the early works of Kachanov [7] and Rabotnov [8], and is also being developed in our time [9-11].The damage parameter $0 \leq \omega \leq 1$ characterizes the totality of microstructural changes in the material caused by the appearance and accumulation of microdefects under operational loads. The damage parameter is interpreted as the relative reduction in the effective load-bearing cross-sectional area due to the accumulation of damages. Material degradation is caused by a gradual decrease in the effective area, which actually bears tensile loads and determines the tensile strength of the sample. With this interpretation, the damage parameter can be represented as follows:

$$
\omega=\left(S-S_{0}\right) / S_{0},
$$

where $S_{0}$ and $\boldsymbol{S}$ is the cross-sectional area of the intact sample and the current cross-sectional area of the tested sample, respectively; $\left(S_{0}-S\right)$ is the area occupied by microvoids and microcracks.

The damage parameter can be obtained by measuring of elastic modulus changes, with this interpretation. According to the hypothesis of equivalent deformation [9], the damage parameter $\omega$ can be found from the relation

$$
\omega=\mathbf{1}-\boldsymbol{E} / \boldsymbol{E}_{\mathbf{0}},
$$

where $\boldsymbol{E}_{\mathbf{0}}$ and $\boldsymbol{E}$ are the elastic modulus of the intact sample and the current modulus value of the tested sample, respectively.

If we use the model of equivalent elastic energy [10], then we can define $\omega$ as a tensor of the fourth rang

$$
\omega=1-\left(E / E_{0}\right)^{1 / 2}
$$

Only one component of the tensor in (3) is nonzero for uniaxial tension [11]. The damage parameter $\omega$ can be found at the uniaxial tension by changing the elastic characteristics, taking into account the representative element of the volume of orthotropic symmetry. It means that the most complex anisotropy that can be represented is orthotropic. The effective elastic properties remained orthotropic with good accuracy even with a high density of interacting cracks, as was shown by the micromechanical analysis [7]. As it was experimentally shown in [12], an assessment of the damage parameter based on the Lemaitre equivalent deformation model [9] gives higher values of the damage parameter compared to models based on the equivalent elastic energy pattern $[10,11]$ and which give very similar numerical values. Therefore, the assessment of the damage parameter $\omega$ according to (3) is the best in comparison with (2) when analyzing the anisotropy of damage to sheet material [12].

The crystallographic texture, which is formed in the process of plastic deformation, also has a significant effect on the accumulation of structural defects and, accordingly, damages [13].

At the same time, the lack of sufficient physical justification of the models (kinetic equations) gives rise to ambiguity in experimental estimates of the damage parameter $\omega$, depending on the method of its determination for the same sample of the material under study [12]. The relationship between the damage parameter and the change in the structural state and texture under external influences can still be obtained only on the basis of the corresponding correlation and regression analysis.

Goal of this article is the study of the effect of extrusion processing with followed rolling and alternating bending as well as texture on elastic properties, damage parameter, crystalline domains sizes $\mathrm{D}$, lattice distortion $\varepsilon$, and dislocation density $\rho$ of $\mathrm{Mg}-5 \% \mathrm{Li}$ alloy.

\section{MATERIALS AND METHODS}

The original cylindrical blanks of the Mg-5\%Li alloy were subjected to processing in two successive modes (conditionally I and II). 
Processing Mode I. The cylindrical Mg-5\% Li ingots with a diameter of $60 \mathrm{~mm}$ and a length of $120 \mathrm{~mm}$ were extruded at $350^{\circ} \mathrm{C}$. Thus slabs $60 \mathrm{~mm}$ wide and $6 \mathrm{~mm}$ thick were obtained. Then the slabs were rolled in the longitudinal direction to a thickness of $4.5 \mathrm{~mm}$ in two passes. Heating to $350^{\circ} \mathrm{C}$ was conducted after each pass.

Processing Mode II. The alloy strips of $4.5 \mathrm{~mm}$ thick obtained after processing in the first mode were rolled then in the transverse direction to a thickness of $2 \mathrm{~mm}$ in 10 passes with reduction of $10 \%$ per pass. The heating was conducted to $350^{\circ} \mathrm{C}$ after each pass. Then, the rolling direction changed by $90^{\circ}$ each time, and thus the sheet was rolled to a thickness of $1 \mathrm{~mm}$ with a decrease of about $10 \%$ per pass.

The sheets of the investigated alloy, processed in accordance with mode II, were next subjected to straightening by means of the alternating bending. Process of sheets straightening by means of the alternating bending was modeled on a manual three-roller device. The diameter of the bending roller was $50 \mathrm{~mm}$. The metal moving speed at the bending was approximately $150 \mathrm{~mm} / \mathrm{s}$. The one cycle consisted of bending in one direction $(0.25$ cycles $)$, returning to a flat state $(0.5$ cycles $)$, bending in the opposite direction $(0.75$ cycles $)$ and straightening ( 1.0 cycle). Studies were performed after 0.5 , $1.0,3.05 .0$ of $\mathrm{AB}$

Young's modulus was measured dynamically by the frequency of natural bending vibrations of flat rectangular samples $100 \mathrm{~mm}$ long and $10 \mathrm{~mm}$ wide. The measurement error of Young's modulus did not exceed 1\%. [14]. Samples were cut out through every $15^{\circ}$ from the rolling direction (RD) up to the transverse direction (TD) from the original sheets processed in accordance with mode II, as well as from the same sheets after 0.5, 1.0, 3.0, and 5.0 cycles of alternating bending. Samples for studying the texture and substructure parameters were also cut out.

We found the damage parameters using changes in the Young's modulus of the processed samples relative to original samples in the corresponding sheet directions according to relations (2) and (3).

Diffraction patterns were recorded to analyze line broadening for defect density description. The high energy materials science beamline HEMS@Petra III /Hasylab DESY (Hamburg-Germany) equipped with a Perkin-Elmer area detector was used to obtain two-dimensional pattern [15]. Synchrotron radiation with energy of $87 \mathrm{keV}$ and a wavelength of $0.014235 \mathrm{~nm}$ a high penetration depth, similar to thermal neutrons [16], allowed the study in the transmission mode. Beam size was $0.5 \mathrm{~mm}$. Calibration of the instrumental set-up, see figure 1 , was performed by a $\mathrm{LaB}_{6}$ standard. The calibration includes determination of the sample to detector distance $(0.901 \mathrm{~m})$, the wavelength and the instrumental line broadening. The shooting scheme is shown in Fig. 1.
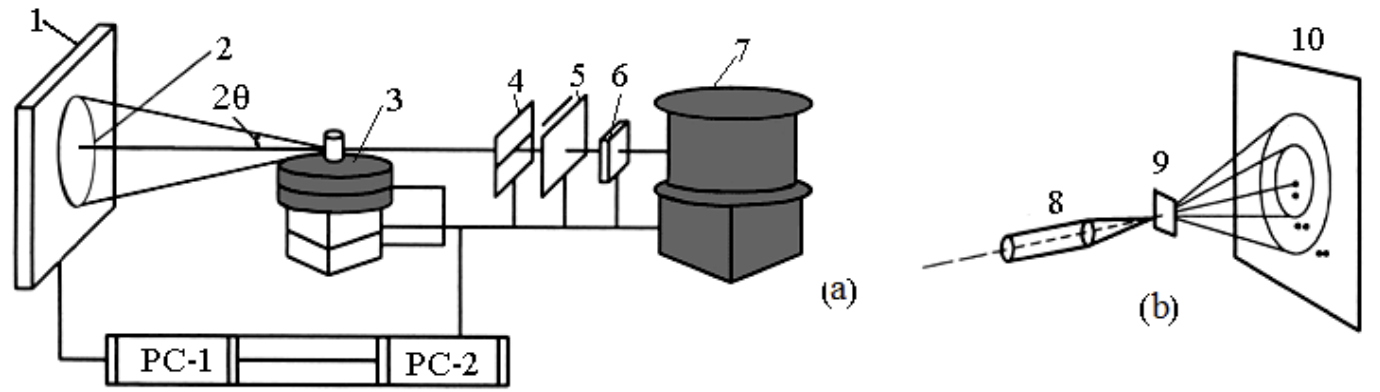

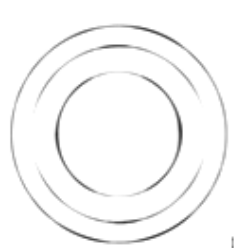

(c)

Fig. 1. Sketch of the set-up using synchrotron radiation beam; (a) diffraction pattern measurement; (b) (b) pin whole technique; (c). example of an area detector image; ((a): 2D detector (1); beam stopper (2); sample (3); vertical and horizontal slots, respectively, (4) and (5); a diode (6); monochromator (7); PC1 and PC2 are rotation and displacement devices, respectively. In scheme (b): a monochromatic beam (8); a sample (9), and a detector (10)).

The microstructure parameters (crystalline domains sizes D, values of crystal lattice distortion $\varepsilon=\Delta d_{h k l} / d_{h k l}$, and dislocation density $\rho$ ) were calculated using standard 1-dimensional diffraction pattern generated by Fit2D [17] from area detector pictures. The analysis of the line broadening was carried out using the Origin-6G computer program. Crystalline domains sizes $\mathrm{D}$, values of crystalline lattice distortion and dislocation density $\rho$ were estimated by means of Williamson-Hall methods [18, 19].

The texture analysis was performed using the method of inverse pole figures (IPF) on the measurements in the normal direction (ND) to the rolling plane (ND IPF) and the rolling direction (RD IPF) taken on a DRON-3M diffractometer by using of the MoK $\alpha$ radiation in reflection mode from two sides of sheets after the corresponding number cycles of AB. The pole densities of IPF were found from the integrated intensity of the diffraction lines with allowance for the sample without texture. A textureless sample was manufactured from small recrystallized sawdust of the investigated magnesium alloy. The Morris normalization was used, when constructing the IPFs [20].

\section{EXPERIMENTAL RESULTS AND DISCUSSION}

Inverse pole figures of the investigated alloy are presented in Fig. 2. The texture of the sheet processed according to I mode is characterized by the presence of a relatively weak basal component (pole density 1.14 in Fig. 2a) and a very strong component $\langle\mathbf{1 0} \overline{\mathbf{1 0}}\rangle$ (pole density 6.64 in Fig. 2a). This corresponds to the texture, at which the normal to the basal plane (0001) is deflected by $90^{\circ}$ to the TD. In this case, the rolling direction of such a sheet coincides mainly with the crystallographic directions $\langle\mathbf{1 1 2} \mathbf{0}\rangle$ with scattering up to $\langle\mathbf{1 0} \overline{\mathbf{1}} \mathbf{0}\rangle$ (Fig. 2b). The addition of lithium to magnesium changes the balance of the deformation mechanisms, which in turn affects the texture. 
Fig. 2c, $d$ is showed the ND IPF and RD IPF of the alloy under study after treatment in the mode II. It can be seen that the hexagonal prism axis is deviated from ND on about 15 to $70^{\circ}$ towards the TD, in contrast to the basal rolling texture of pure magnesium. The crystallographic direction $\langle\mathbf{2 1} \overline{\mathbf{3}} \mathbf{1}\rangle$ (pole density 3.70) coincides mainly with the RD (Fig. 2d). At the same time, it should be noted that the region of increased pole density on inverse pole figure of the rolling direction occupies a rather wide region between poles $\langle\mathbf{3 0} \overline{\mathbf{3}} \mathbf{2}\rangle,\langle\mathbf{1 1 2} \mathbf{2}\rangle$ and $\langle\mathbf{1 0} \overline{\mathbf{1}} \mathbf{0}\rangle$.
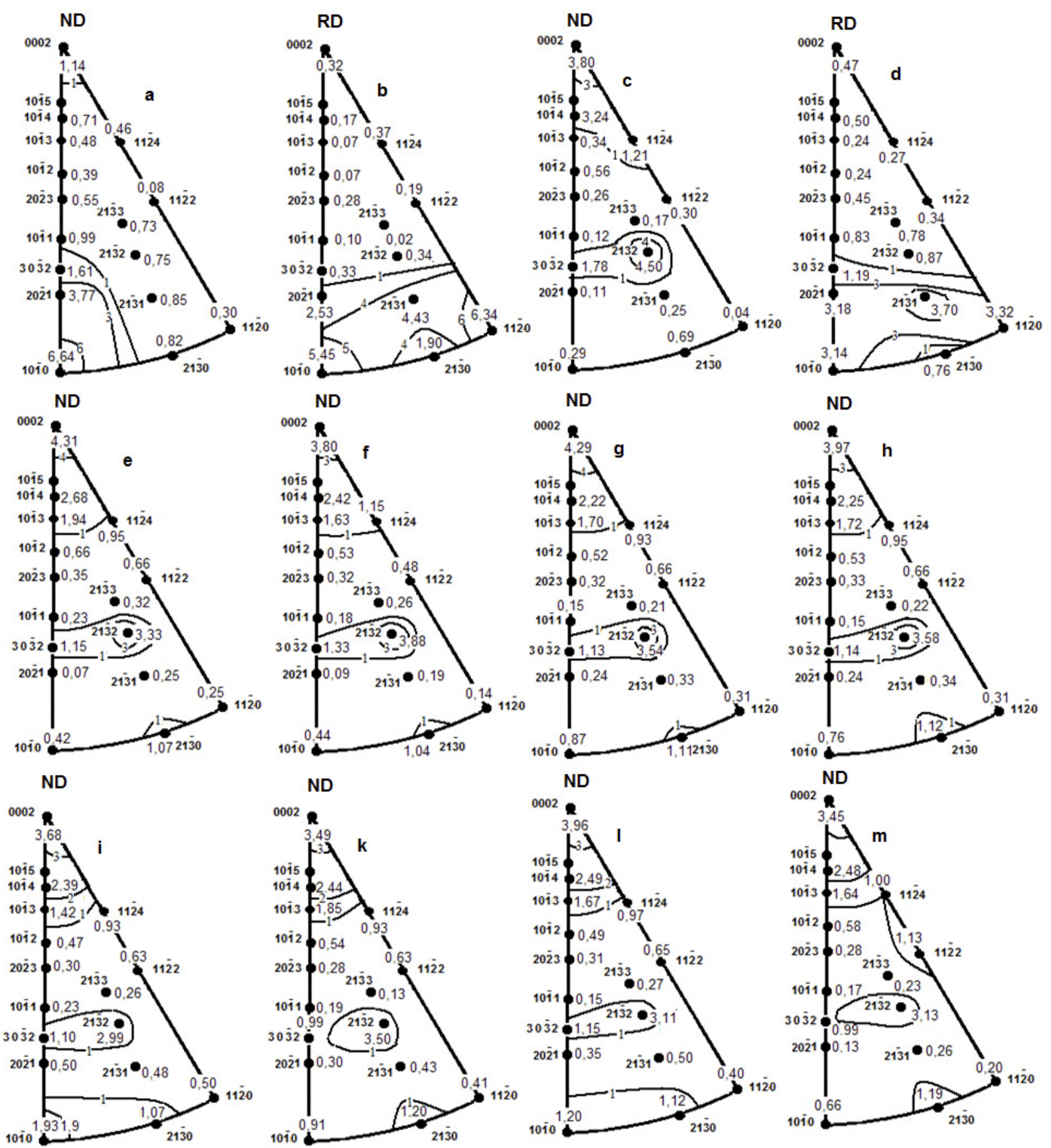

Fig. 2. Experimental inverse pole figures of alloy $\mathrm{Mg}-5 \% \mathrm{Li}$ : $(\mathrm{a}, \mathrm{b})$ are after extrusion and rolling in longitudinal direction (Proceeding Mode I); (c, d) are extrusion and rolling with changing direction (Proceeding Mode II), (e-m) are after processing in accordance with the mode II and subsequent alternating bending using different number of cycles: 0.5 (e, f); 1.0 (g, h); 3.0 (i, k), and $5.0(1, \mathrm{~m})$ cycles. $(\mathrm{f}, \mathrm{h}, \mathrm{k}, \mathrm{m})$ correspond to the stretched side of the sheet; $(\mathrm{e}, \mathrm{g}, \mathrm{i}, \mathrm{l})$ correspond to the compressed side of sheets of alloy

Doping of magnesium with lithium reduces the $c / a$ axis ratio and thereby activates not basal sliding mechanisms. In particular, at elevated temperatures, the role of the prismatic $<a>$ slip of dislocations in $\mathrm{Mg}$ - $\mathrm{Li}$ alloys can be significant [4]. Formation of the texture components of the basal type deviated up to the TD is probably facilitated by activation of the prismatic $<a>$ slip, as well as twinning (Fig. 3). 
The type, nature and degree of texture scattering after alternating bending depends on the cycle's number of alternating bending, as mentioned above. A more detailed description of the texture and microstructure after the AB can be found in [6].

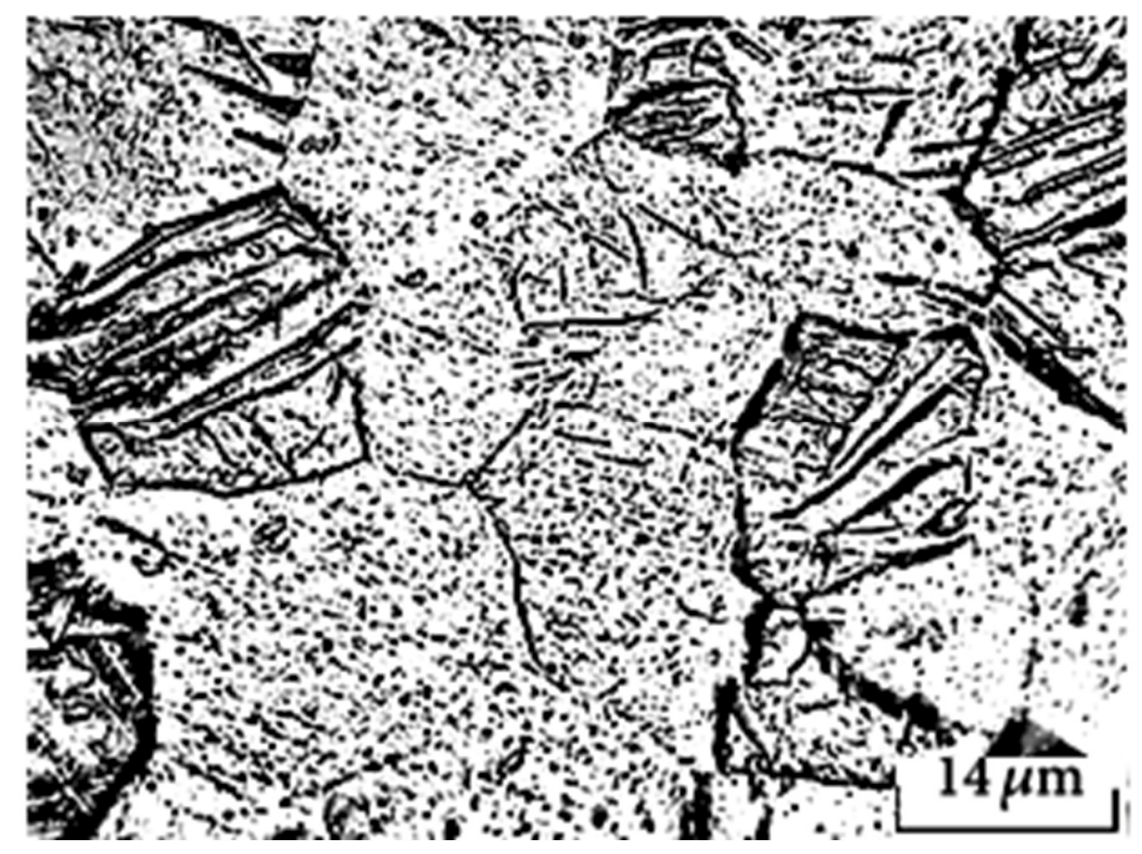

Fig. 3. Microstructure of Mg-5\%Li alloy machined by Proceeding Mode I

The integrated diffraction spectra of the $\mathrm{Mg}-5 \% \mathrm{Li}$ alloy treated in according with the processing mode II, as well as after a different number of cycles of alternating bending are shown in Fig. 4.

Lattice distortion is evaluated usually on the basis of the classical Williamson-Hall method [18]. This method gives good results in the absence of anisotropy of the broadening of diffraction lines.

Anisotropy of the physical broadening of the diffraction lines due to the crystallographic texture of the samples in the studied alloy (Fig's. 2, 4) was found. Therefore, further analysis was performed using the modified Williamson Hall method [19]. The method for processing the width of diffraction peaks makes it possible to estimate the dislocations density. Assuming that the strain broadening of the lines is due to dislocations and that the average dislocation contrast factor $(\bar{C})$ is known, the full width at half maximum (FWHM) of the X-ray diffraction peak (XRD) with allowance for instrumental correction and correction for absorption can be represented using a modified equation Williamson - Hall as follows [19]:

$$
\mathrm{FWHM}=\frac{0,9}{\mathrm{D}}+\frac{\left(\pi \mathrm{M}^{2} \mathrm{~b}^{2}\right)}{2} \rho^{1 / 2}\left(\mathrm{~K} \overline{\mathrm{C}}^{1 / 2}\right)^{2}+\mathrm{O}\left(\mathrm{K} \overline{\mathrm{C}}^{1 / 2}\right)^{4}
$$

Here $D, b$, and $\rho$ are, respectively, the crystalline domain size, the absolute value of the Burgers vector of the dislocation, and the dislocations density. So called dislocation arrangement parameter $M$ is depended on the outer effective cut-off radius of dislocations, $K=(2 \sin \theta) / \lambda, \theta$ is the diffraction angle, $\lambda$ is the radiation wavelength, $\mathrm{O}$ is the highest order of the value $K \bar{C}^{1 / 2}$.

For the convenience of further analysis, we introduce the following notation:

The relation (6) takes such form at the new notation:

$$
\mathrm{FWHM}=\mathrm{y} ;(0.9 / \mathrm{D})=\mathrm{C} ;\left[\frac{\left(\pi \mathrm{M}^{2} \mathrm{~b}^{2}\right)}{2} \rho^{1 / 2}\right]=\mathrm{B} ;\left(\mathrm{KC} \overline{\mathrm{C}}^{1 / 2}\right)^{2}=\mathrm{x} ; \mathrm{O}\left(\mathrm{KC} \overline{\mathrm{C}}^{1 / 2}\right)^{4}=\mathrm{Ax}^{2}
$$

$$
y=C+B x+\mathrm{Ax}^{2}
$$

In metals and alloys with a hexagonal lattice, one should take into account the manifold of 11 different slip systems and the corresponding Burgers vectors [21]. They can be divided into three main slip systems with the following Burgers vectors: $b_{1}=1 / 3\langle 11 \overline{2} 0\rangle$ ( $\langle a\rangle$ type), $b_{2}=\langle 0001\rangle\left(\langle c\rangle\right.$ type) and $b_{3}=\langle 11 \overline{2} 3\rangle(\langle c+a\rangle$ type). The average dislocation contrast factor $(\bar{C})$ for various slip systems during deformation of pure magnesium can be determined from [21]. However, as mentioned above, alloying magnesium with lithium leads to the change as the $c / a$ ratio as well the elastic constants magnitude. So for pure magnesium $(c / a)=1.624$ [22]. For the studied alloy $\mathrm{Mg}-5 \% \mathrm{Li}$ $c / a=1.610$, according to our data.

The elastic constants of the Mg-5\%Li alloy were calculated by us earlier [23]. The results are shown in Table 1. 
Table 1

Elastic modules of single crystal of Mg-5\%Li alloy

\begin{tabular}{|l|l|c|c|c|}
\hline \multicolumn{5}{|c|}{ Elastic modules of single crystal of Mg (mass) $5 \%$ Li alloy, GPa } \\
\hline $\mathrm{C} 11$ & $\mathrm{C} 12$ & $\mathrm{C} 13$ & $\mathrm{C} 33$ & $\mathrm{C} 44$ \\
\hline 51.2 & 20.1 & 17.1 & 64.7 & 19.8 \\
\hline
\end{tabular}

The average values of the parameters of the dislocation contrast of the studied alloy were calculated using the freely distributed computer program ANIZC [24]. For this purpose, we used the elastic constants given in the Table 1.In this case, we took into account the influence of both edge and screw dislocations of the $\langle\mathrm{a}\rangle,\langle\mathrm{a}+\mathrm{c}\rangle,\langle\mathrm{c}\rangle$ type in the ratio of 0.6, 0.38, 0.02 respectively [25] for the diffraction lines shown in Fig. 4.
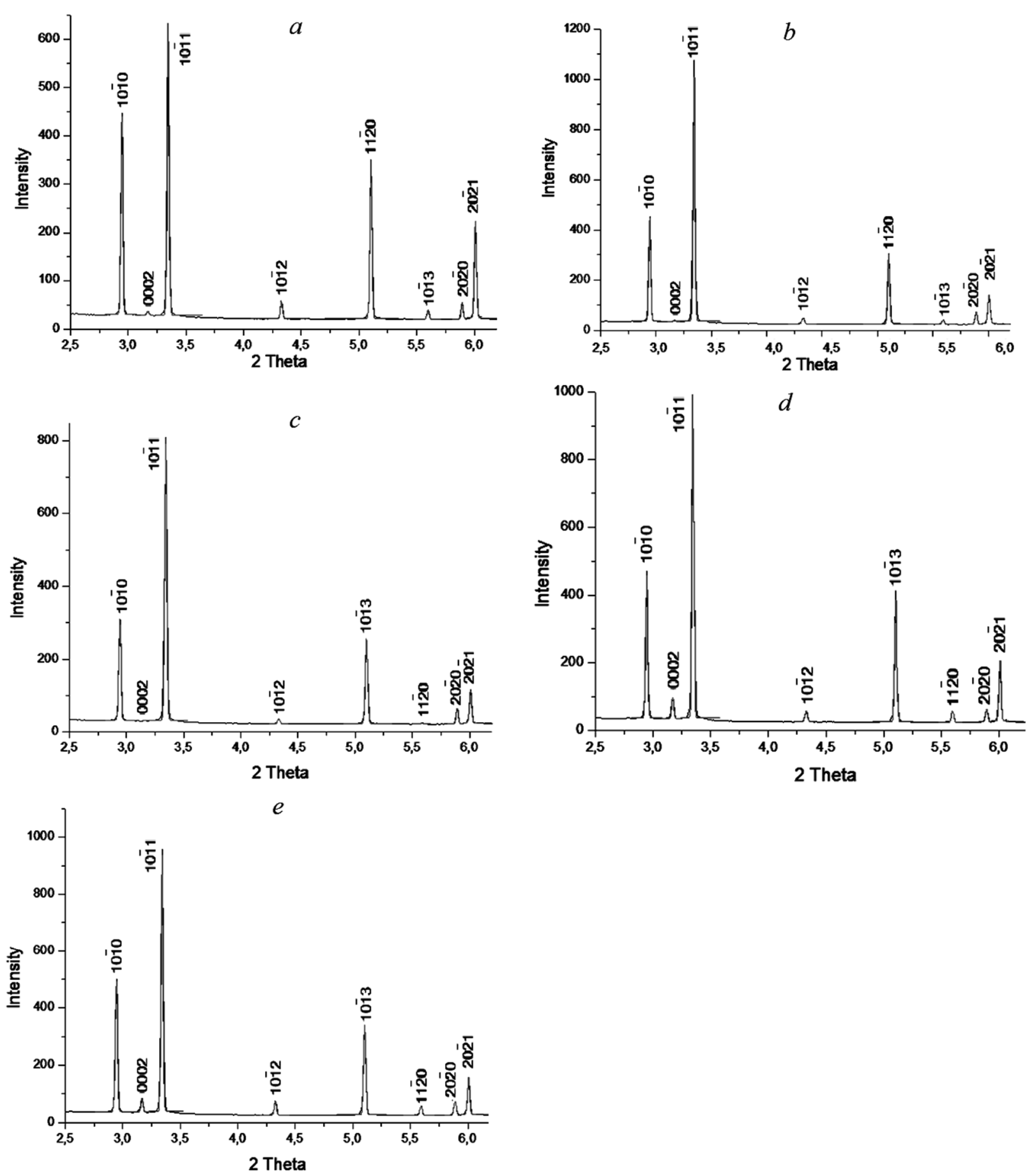

Fig. 4. Integral diffraction spectra of the alloy Mg-5\%Li: (a) after treatment by proceeding mode II, extrusion and rolling with changing direction; (b-e) after subsequent alternating bending using various numbers of cycles: 0.5 (b); 1.0 (c); 3.0 (d), and 5.0 (e) cycles 
The average value of the Burgers vector of dislocations turned out to be $0.151 \mathrm{~nm}$. In [25] the influence of equal channel angular pressing (ECAP) on the crystalline domains sizes, lattice distortion, and the dislocation density of the AZ91 magnesium alloy were studied. It was shown that the parameter M (6) decreases from 2.5 to 1.6 during processing. We accepted the value of the parameter M equal to 2 to assess the dislocation density of studied alloy $\mathrm{Mg}-$ $5 \% \mathrm{Li}(\mathrm{wt})$.

As a result of our calculations, we obtained the following relationships of type ( $6 \mathrm{a})$ both for the original samples obtained by processing in modes I and II, and for samples after alternating bending (Table 2).

Table 2

Modified Williamson-Hall Equations for Mg-5\%Li alloy

\begin{tabular}{|c|c|c|c|}
\hline $\begin{array}{c}\text { Processing } \\
\text { mode }\end{array}$ & $\begin{array}{c}\text { Cycles number of } \\
\text { alternating } \\
\text { bending }\end{array}$ & Equations (6a) & $\begin{array}{c}\text { Approximation } \\
\text { reliability factor } R^{2}\end{array}$ \\
\hline I & 0 & $y=0.02184+0.0006 x+0.00044 x^{2}$ & 0.98 \\
\hline II & 0 & $y=0.02282+0.0055 x+0.00007 x^{2}$ & 0.98 \\
\hline II & 0.5 & $y=0.02487+0.00062 x+0.00005 x^{2}$ & 0.99 \\
\hline II & 1.0 & $y=0.02360+0.00067 x+0.00001 x^{2}$ & 0.98 \\
\hline II & 3.0 & $y=0.02493+0.00074 x+0.00009 x^{2}$ & 0.99 \\
\hline II & 5.0 & $y=0.02554+0.00078 x+0.00003 x^{2}$ & 0.99 \\
\hline
\end{tabular}

If the magnitude of the coefficient $\mathrm{B}$ is known, then the dislocation density can be estimated, as this follows from equations (6) and (6a). The results of analysis of the substructure (distortion of the crystal lattice $\varepsilon$, crystallite domains sizes $D$ and dislocation density $\rho$ ) after processing according to the I and II Modes, and also after different number $\mathrm{n}$ of $\mathrm{AB}$ cycles are presented in Table 3.

Table 3

Substructure parameters of the $\mathrm{Mg}-5 \% \mathrm{Li}$ alloy after various processing

\begin{tabular}{|c|c|c|c|c|c|c|}
\hline \multirow{3}{*}{$\begin{array}{c}\text { Structure } \\
\text { Characteristics }\end{array}$} & \multirow{3}{*}{$\begin{array}{l}\text { Processing } \\
\text { Mode I }\end{array}$} & $\begin{array}{c}\text { Processing } \\
\text { Mode II }\end{array}$ & \multicolumn{4}{|c|}{ Alternating bending } \\
\hline & & \multicolumn{5}{|c|}{ Cycles number, $n$} \\
\hline & & 0 & 0,5 & 1 & 3 & 5 \\
\hline$D, \mathrm{~nm}$ & 41 & 39 & 38 & 37 & 36 & 35 \\
\hline$\varepsilon \times 10^{-4}$ & 5.86 & 2.03 & 2.31 & 2.39 & 2.91 & 3.15 \\
\hline$\rho \times 10^{14}, \mathrm{~m}^{-2}$ & 2.19 & 2.11 & 2.51 & 3.13 & 3.82 & 4.25 \\
\hline
\end{tabular}

The sizes of the crystalline domains D decrease, while the lattice distortion $\varepsilon$ and the dislocation density $\rho$ increase with increasing of the cycle number of alternating bending (Table 3). Strong correlations take places between the value of the substructure parameters of the alloy processed according to mode II and the number $n$ of AB cycles. The corresponding regression equations and approximation reliability coefficients have the form:

$$
\begin{gathered}
D=0.014 n^{2}-1.44 n+38.73 ; R^{2}=0.96 \\
\varepsilon \times 10^{-4}=-0.034 n^{2}+0.386 n+2.063 ; R^{2}=0.99 \\
\rho \times 10^{14}=-0.087 n^{2}+0.831 n+2.232 ; R^{2}=0.98
\end{gathered}
$$

Table 4 presents values of the elastic modulus $E$ in different directions of the sheets of the alloy under study and the anisotropy coefficients $\eta$ after processing according to mode II as well as after different number of cycles of the subsequent alternating bending. The value of anisotropy coefficients $\eta$ can be found by the ratio:

$$
\eta=\left[\left(F_{\max }-F_{\min }\right) / F_{\min }\right] \cdot 100 \%
$$

where $F$ is the value of the corresponding property.

The directionally averaged values of the elastic modulus $E$ decrease with an increase in the number of AB cycles (Table 4). The analysis showed that there is a strong correlation between the directionally averaged elastic modulus values $E$ and the number $n$ of $\mathrm{AB}$ cycles. The corresponding regression equation and approximation reliability coefficient have the form:

$$
E_{a v}=0.29 n^{2}-2.30 n+50.96 ; R^{2}=0.85
$$

To study the effect of alternating bending on the damage parameter $\omega$, we assume that the samples of the studied alloy immediately after treatment in the mode II have not damages and are characterized by elastic modules $E_{0}$, and after the corresponding number of $\mathrm{AB}$ cycles, the samples are characterized by elastic modules $E$. 
Modules of elasticity $(E)$ and coefficients of anisotropy $(\eta)$ after various treatment of Mg-5\%Li alloy sheets

\begin{tabular}{|c|c|c|c|c|c|c|c|c|c|c|}
\hline \multirow{4}{*}{$\begin{array}{c}\text { Angle } \\
\text { with } \\
\text { rolling } \\
\text { direction } \\
\end{array}$} & \multicolumn{10}{|c|}{ Processing mode } \\
\hline & \multirow{2}{*}{\multicolumn{2}{|c|}{ Processing mode II $(0)$}} & \multicolumn{8}{|c|}{ Alternating bending cycles number } \\
\hline & & & \multicolumn{2}{|c|}{0.5} & \multicolumn{2}{|c|}{1.0} & \multicolumn{2}{|c|}{3.0} & \multicolumn{2}{|c|}{5.0} \\
\hline & $E, \mathrm{GPa}$ & $\eta, \%$ & $\begin{array}{c}E, \\
\mathrm{GPa}\end{array}$ & $\eta, \%$ & $E, \mathrm{GPa}$ & $\eta, \%$ & $E, \mathrm{GPa}$ & $\eta, \%$ & $E, \mathrm{GPa}$ & $\eta, \%$ \\
\hline 0 & 50.3 & \multirow{7}{*}{5.2} & 48.2 & \multirow{7}{*}{3.3} & 46.8 & \multirow{7}{*}{10.9} & 44.2 & \multirow{7}{*}{11.8} & 46.2 & \multirow{7}{*}{3.3} \\
\hline 15 & 50.6 & & 48.1 & & 46.8 & & 45.3 & & 46.1 & \\
\hline 30 & 51.3 & & 48.0 & & 47.1 & & 47.9 & & 46.2 & \\
\hline 45 & 52.1 & & 48.2 & & 49.5 & & 49.4 & & 46.2 & \\
\hline 60 & 52.6 & & 48.7 & & 51.0 & & 49.1 & & 46.7 & \\
\hline 75 & 52.8 & & 49.3 & & 51.1 & & 47.2 & & 47.3 & \\
\hline 90 & 52.9 & & 49.6 & & 51.9 & & 46.2 & & 47.6 & \\
\hline $\begin{array}{l}\text { Average } \\
\text { value }\end{array}$ & 51.8 & 5.2 & 48.6 & 3.3 & 49.2 & 10.9 & 47.0 & 11.8 & 46.6 & 3.3 \\
\hline
\end{tabular}

The values of the damage parameter $\omega$ according to relations (2) and (3) are presented in Tables 5 and 6.

The analysis showed that there are strong correlations between the damage parameters $\omega_{1}$ and $\omega_{2}$ averaged over the directions in sheets of the investigated alloy, on the one hand, and the number of AB cycles, on the other hand (Tables 5, 6).

Table 5

Damage parameters $\omega_{1}$ and anisotropy coefficients after various processing of Mg-5\%Li alloy sheets

\begin{tabular}{|c|c|c|c|c|c|c|c|c|c|c|}
\hline \multirow{4}{*}{$\begin{array}{l}\text { Angle } \\
\text { with } \\
\text { rolling } \\
\text { direction }\end{array}$} & \multicolumn{10}{|c|}{ Processing mode } \\
\hline & \multicolumn{10}{|c|}{ Alternating bending cycles number } \\
\hline & \multicolumn{2}{|c|}{ Processing mode II (0) } & \multicolumn{2}{|c|}{0.5} & \multicolumn{2}{|c|}{1.0} & \multicolumn{2}{|c|}{3.0} & \multicolumn{2}{|c|}{5.0} \\
\hline & $\omega_{1}=1-E / E_{0}$ & $\eta, \%$ & $\omega_{1}$ & $\eta, \%$ & $\omega_{1}$ & $\eta, \%$ & $\omega_{1}$ & $\eta, \%$ & $\omega_{1}$ & $\eta, \%$ \\
\hline 0 & \multirow{7}{*}{0} & \multirow{7}{*}{0} & 0.042 & \multirow{7}{*}{79} & 0.070 & \multirow{7}{*}{332} & 0.121 & \multirow{7}{*}{144} & 0.082 & \multirow{7}{*}{38} \\
\hline 15 & & & 0.049 & & 0.075 & & 0.105 & & 0.089 & \\
\hline 30 & & & 0.06 .4 & & 0.082 & & 0.066 & & 0.099 & \\
\hline 45 & & & 0.07 .5 & & 0.050 & & 0.052 & & 0.113 & \\
\hline 60 & & & 0.074 & & 0.030 & & 0.067 & & 0.112 & \\
\hline 75 & & & 0.067 & & 0.032 & & 0.106 & & 0.104 & \\
\hline 90 & & & 0.062 & & 0.019 & & 0.127 & & 0.100 & \\
\hline $\begin{array}{l}\text { Average } \\
\text { value } \omega_{1}\end{array}$ & 0 & 0 & 0.062 & 79 & 0.051 & 332 & 0.092 & 144 & 0.100 & 38 \\
\hline
\end{tabular}

Damage parameters $\omega_{2}$ and anisotropy coefficients after various processing of $\mathrm{Mg}-5 \% \mathrm{Li}$ alloy sheets

\begin{tabular}{|c|c|c|c|c|c|c|c|c|c|c|}
\hline \multirow{4}{*}{$\begin{array}{l}\text { Angle } \\
\text { with } \\
\text { rolling } \\
\text { direction }\end{array}$} & \multicolumn{10}{|c|}{ Processing mode } \\
\hline & \multicolumn{10}{|c|}{ Alternating bending cycles number } \\
\hline & \multicolumn{2}{|c|}{ Processing mode II (0) } & \multicolumn{2}{|c|}{0.5} & \multicolumn{2}{|c|}{1.0} & \multicolumn{2}{|c|}{3.0} & \multicolumn{2}{|c|}{5.0} \\
\hline & $\omega_{2}=1-\left(E / E_{0}\right)^{1 / 2}$ & $\eta, \%$ & $\omega_{2}$ & $\eta, \%$ & $\omega_{2}$ & $\eta, \%$ & $\omega_{2}$ & $\eta, \%$ & $\omega_{2}$ & $\begin{array}{l}\eta, \\
\%\end{array}$ \\
\hline 0 & \multirow{7}{*}{0} & \multirow{7}{*}{0} & 0.021 & \multirow{7}{*}{81} & 0.035 & \multirow{7}{*}{340} & 0.063 & \multirow{7}{*}{149} & 0.042 & \multirow{7}{*}{40} \\
\hline 15 & & & 0.025 & & 0.038 & & 0.054 & & 0.046 & \\
\hline 30 & & & 0.033 & & 0.042 & & 0.034 & & 0.051 & \\
\hline 45 & & & 0.038 & & 0.025 & & 0.026 & & 0.058 & \\
\hline 60 & & & 0.038 & & 0.015 & & 0.034 & & 0.058 & \\
\hline 75 & & & 0.034 & & 0.016 & & 0.055 & & 0.054 & \\
\hline 90 & & & 0.032 & & 0.009 & & 0.065 & & 0.051 & \\
\hline $\begin{array}{l}\text { Average } \\
\text { value } \omega_{2}\end{array}$ & 0 & 0 & 0.032 & 81 & 0.026 & 340 & 0.047 & 149 & 0.051 & 40 \\
\hline
\end{tabular}


The corresponding regression equations and approximation reliability coefficients $R^{2}$ have the form:

$$
\begin{aligned}
& \omega_{1}=-0.005 n^{2}+0.044 n+0.016 ; R^{2}=0.85 \\
& \omega_{2}=-0.002 n^{2}+0.022 n+0.008 ; R^{2}=0.86 .
\end{aligned}
$$

The value of the damage parameter averaged over all directions in the sheets, increases with an increase in the number of $\mathrm{AB}$ cycles to 5 in accordance with relations (12) and (13). Anisotropy of the both elastic modulus and damage parameters takes place, both in the original sheet processed according to the mode II and after alternating bending (Tables 4-6).

The anisotropy of the elastic modulus reaches its maximum value after 3 cycles of AB. Anisotropy coefficients of the damage parameters are maximal after 1 cycle of AB. Minimum of the anisotropy is observed after 5 cycles of AB (Tables 4-6).

The effect of the crystallographic texture on the anisotropy of elastic properties, as well as of lattice distortion, crystalline domains sizes, dislocation density and damage parameters after the corresponding number of alternating bending cycles can be established by comparing the values of the above properties in different sheet directions with the pole density values at the corresponding inverse pole figures for the normal direction (ND IPFs). Changes in the texture can be described quantitatively by a change in the normalized values of the pole density exceeding 1 (which corresponds to a sample without texture) on the IPF ND (Fig. 2). We assume that only crystallite orientations whose normalized pole density is greater than unity contribute to the anisotropy of properties. In this case, it is necessary to renormalize the pole density taking into account only the above orientations.

For this purpose, first we average the values of the pole density (exceeding 1) on the ND IPF's obtained for two sides of the sheets after each number of cycles of alternating bending (Fig. 2). Sums of the average values of the above pole densities we use as normalization factors $\sum P_{h k i l}^{a v}$ for the corresponding number of cycles to determine the relative contribution to the texture of each of the above $P_{h k i l}^{a v}$ for each number of cycles. For this, we find the relations $P_{h k i l}^{a v} / \sum P_{h k i l}^{a v}$ for the corresponding number of $\mathrm{AB}$ cycles. In principle, the last relation has the sense of the volume fraction of the corresponding texture component in the above approximation.

The contribution of each texture component to the corresponding properties we will taken into account in the form of sums of the products $P_{h k i l}^{a v}$ on its volume fraction of $P_{h k i l}^{a v} / \sum P_{h k i l}^{a v}$, i.e. $\sum\left(P_{h k i l}^{a v} \times\left(P_{h k i l}^{a v} / \sum P_{h k i l}^{a v}\right)\right)$. We will call them "relative normalized values of the pole density" $P_{\text {rel }}$. These values are summarized in the Table 7 .

Normalized values of pole densities exceeding 1 on the IPF ND

Table 7

\begin{tabular}{|c|c|c|c|c|c|}
\hline Cycles number & 0 & 0.5 & 1.0 & 3.0 & 5.0 \\
\hline$P_{\text {rel }}$ & 3.43 & 2.92 & 2.89 & 2.51 & 2.53 \\
\hline
\end{tabular}

The analysis showed that there are significant correlations between the $P_{\text {rel }}$ values (Table 7), on the one hand, the crystalline domains sizes $D$, the lattice distortion $\varepsilon$, the dislocation density $\rho$ (Table 3 ), the elastic modulus $E_{a v}$ averaged over the direction in the sheets of the studied alloy (Table 4) and damage parameters $\omega_{1}, \omega_{2}$ (Tables 5,6$)$, on the other hand.

The corresponding regression equations and approximation reliability coefficients have the form:

$$
\begin{gathered}
D=-2.40 P_{r e l}^{2}+18.11 P_{r e l}+5.08 ; R^{2}=0.90 \\
\varepsilon \cdot 10^{-4}=1.22 P_{r e l}^{2}-8.37 P_{r e l}+16.35 ; R^{2}=0.95 \\
\rho \cdot 10^{14}=1.48 P_{r e l}^{2}-100.95+22.20 ; R^{2}=0.93 \\
E=-0.19 P_{r e l}^{2}+4.32 P_{r e l}-34.70 ; R^{2}=0.98 \\
\omega_{1}=-0.007 P_{r e l}^{2}-0.058 P_{r e l}+0.293 ; R^{2}=0.98 \\
\omega_{2}=-0.004 P_{r e l}^{2}-0.025 P_{r e l}+0.142 ; R^{2}=0.97
\end{gathered}
$$

Kearns texture coefficients are often used to quantify the texture of hexagonal materials [26]. These coefficients $f_{j}$ (the index $j$ means the corresponding direction in the sample (ND, RD or TD) express the degree of directivity of the 
c-axes of the crystalline HCP cell of grains with a given geometric direction in the polycrystalline material and can be found from the inverse pole figure by the ratio [27]:

$$
f_{j}=\left\langle\cos ^{2} \alpha_{i}\right\rangle_{j}=\sum_{i} A_{i} P_{j i} \cos ^{2} \alpha_{i}
$$

Where $P_{j i}=\frac{I_{i} / I_{R}}{\sum_{\Delta}\left(A_{i} I_{i} / I_{R}\right)} ; I_{i} / I_{R}$ is the ratio of the integrated intensity $I_{i}$ of $i$-th reflection at the $j$-th IPF to the corresponding value for the sample without texture $I_{R} ; A_{i}$ are the statistical weights of the $i$ reflection $\left(\sum A_{i} P_{j i}=1\right)$ [20]; $\alpha_{i}$ is the deviation angle of the $i$-th crystallographic direction of the $\mathrm{c}$ axis the $j$ direction in the sample.

To find the Kearns texture coefficients by equation (20), we used the IPF in Fig. 2, the values of $A_{i}$ taken from [28]. We calculated the angles $\alpha_{i}$ according to well-known formulas using the above mentioned $c / a=1.61$ ratio for $\mathrm{Mg}-5 \% \mathrm{Li}$ alloy.

The Kearns texture coefficients calculated by ND IPF $\left(f_{N D}\right)$ and by RD IPF $\left(f_{R D}\right)$ for the sheets obtained by processing in the Mode I were, respectively, 0.232 and 0.142 . Kearns texture coefficients $\left(f_{N D}\right)$ and $\left(f_{R D}\right)$ of the original alloy sheet processed by mode II are shown in Table 8. In Table 8 are also shown the Kearns texture coefficients calculated by the ND IPF of both sheets sides $\left(f_{N D}^{(1)}, f_{N D}^{(2)}\right)$, as well as after averaging by two sides sheets alloy ( $\mathrm{f}_{\mathrm{ND}}^{(\mathrm{av})}$ ) after various number of alternating bending cycles.

The Kearns texture coefficients calculated from the IPF data in Fig. 2.

Table 8

\begin{tabular}{|c|c|c|c|c|c|c|c|c|c|c|c|c|c|}
\hline \multicolumn{14}{|c|}{ Processing Mode II } \\
\hline \multicolumn{14}{|c|}{ Alternating bending } \\
\hline \multicolumn{14}{|c|}{ Cycles number } \\
\hline \multicolumn{2}{|c|}{0} & \multicolumn{3}{|c|}{0.5} & \multicolumn{3}{|c|}{1.0} & \multicolumn{3}{|c|}{3.0} & \multicolumn{3}{|c|}{5.0} \\
\hline$f_{N D}$ & $f_{R D}$ & $f_{N D}^{(1)}$ & $f_{N D}^{(2)}$ & $f_{N D}^{(a v)}$ & $f_{N D}^{(1)}$ & $f_{N D}^{(2)}$ & $f_{N D}^{(a v)}$ & $f_{N D}^{(1)}$ & $f_{N D}^{(2)}$ & $f_{N D}^{(a v)}$ & $f_{N D}^{(1)}$ & $f_{N D}^{(2)}$ & $f_{N D}^{(a v)}$ \\
\hline 0.390 & 0.393 & 0.435 & 0.407 & 0.421 & 0.409 & 0.388 & 0.398 & 0.399 & 0,411 & 0.404 & 0.417 & 0.411 & 0.414 \\
\hline
\end{tabular}

The mismatches in the distribution of pole density at the ND pole figures of the opposite sheets sides after the corresponding number of cycles of alternating bending were revealed, as can be seen in fig. $2(\mathrm{e}-\mathrm{m})$. This is due to the fact that on the convex side, the surface layers of the sample undergo tensile deformation (Fig. $2 \mathrm{f}, \mathrm{h}, \mathrm{k}$, m), while the layers on the opposite side of the sheet undergo compression deformation (Fig. 2, e, g, i, l). During extension, on the contrary, the metal layers on the convex side of the sheet undergo compression deformation, while the metal layers on the concave side of the sheet experience tensile deformation. Similar discrepancies were found earlier in the work [27] at the investigation of the crystallographic texture of $\mathrm{Zr}-2.5 \% \mathrm{Nb}$ alloy strip. The strip was obtained by straightening part of the pipe after cut along axis. Discrepancies in the distribution of pole density on the ND IPFs of the opposite sides of the sheets of the alloy under study after a different number of alternating bending cycles naturally reflected on the values of the corresponding Kearns texture coefficients (Table 8).

The Kerns texture coefficient $f_{N D}$ of the studied alloy original sheet processed according to Mode II, as well as the average Kerns texture coefficients $f_{N D}^{a v}$ after a different number of alternating bending cycles (Table 8), we used to further analyze their relationship with the sizes of the crystalline domains $D$, of the crystal lattice distortion $\varepsilon$, dislocation density $\rho$ (Table 3 ), as well as with the averaged by the sheet directions Young's modulus $E$ (Table 4 ) and damage parameters $\omega_{1}$ and $\omega_{2}$ after the corresponding number of alternate bending cycles (Table 5,6).

The analysis showed that there are significant correlations between the $f_{N D}^{a v}$ values (Table 8), on the one hand, the crystalline domains sizes $D$, the lattice distortion $\varepsilon$, the dislocation density $\rho$ (Table 3 ), the elastic modulus $E_{a v}$ averaged over the direction in the sheets of the studied alloy (Table 4) and damage parameters $\omega_{1}, \omega_{2}$ (Tables 5,6), on the other hand.

The corresponding regression equations and approximation reliability coefficients have the form:

$$
\begin{gathered}
D=10880\left(f_{N D}^{(a v)}\right)^{2}-8865,7 f_{N D}^{(a v)}+1841,5 ; R^{2}=0.97 \\
\varepsilon \cdot 10^{-4}=-3192,8\left(f_{N D}^{(a v)}\right)^{2}+2607,2 f_{N D}^{(a v)}-529,3 ; R^{2}=0.79 \\
\rho \cdot 10^{14}=-69045,5\left(f_{N D}^{(a v)}\right)^{2}+5024,4 f_{N D}^{(a v)}-1142 ; R^{2}=0.85 \\
E=13430,0\left(f_{N D}^{(a v)}\right)^{2}-11010,0+2303,1 R^{2}=0.97 \\
\omega_{1}=-257,6\left(f_{N D}^{(a v)}\right)^{2}+211,3 f_{N D}^{(a v)}=43,2 ; R^{2}=0.97 \\
\omega_{2}=-130,8\left(f_{N D}^{(a v)}\right)^{2}+107,2 f_{N D}^{(a v)}-21,93 ; R^{2}=0.97
\end{gathered}
$$




\section{CONCLUSION}

It was studied the effect of the processing regime I (deformation by extrusion, rolling after extrusion in combination with annealing), as well as the effect of successive regime II (strips after processing in accordance with the regime I, were rolled further in combination with annealing and changing the direction of rolling) on the texture, .substructure characteristics (crystalline domains sizes, lattice distortions, and dislocation density) of the $\mathrm{Mg}-5 \% \mathrm{Li}$ (wt.) alloy sheets.

It was found that after the $\mathrm{Mg}-5 \% \mathrm{Li}$ alloy treatment in accordance with regime $\mathrm{I}$, a texture is formed in the sheets, at which the axis of the hexagonal prism is $90^{\circ}$ deflected from ND to TD. The crystallographic directions $\langle 12 \overline{2} 0\rangle$ and $\langle 10 \overline{1} 0\rangle$ coincide with $\mathrm{RD}$. In that case the crystalline domains size $D=41 \mathrm{~nm}$, lattice distortions value $\varepsilon=5.86 \cdot 10^{-4}$, and dislocation density $\rho=2.19 \cdot 10^{14} \mathrm{~m}^{-2}$.

After the $\mathrm{Mg}-5 \% \mathrm{Li}$ alloy treatment in accordance with regime II, a texture is formed in the sheets, at which the axis hexagonal prism is deviated from ND to TD by angles ranging from 15 to $70^{\circ}$, in contrast to the texture of basal type after rolling of the pure magnesium. The crystallographic direction $\langle 21 \overline{3} 1\rangle$ coincides with RD. In that case the crystalline domains size $D=39 \mathrm{~nm}$, lattice distortions value $\varepsilon=2.03 \cdot 10^{-4}$, and dislocation density $\rho=2.11 \cdot 10^{14} \mathrm{~m}^{-2}$.

The effect of subsequent alternating bending of the Mg-5\% Li (wt.) alloy sheets processed in accordance with regime II on texture, substructure characteristics (crystalline domains sizes, lattice distortions, and dislocation density), elastic properties and damage parameters of sheets has been also studied. It was found that values of crystalline domains sizes $D$ and elastic modulus $E$ averaged over all directions in the sheets are decreased, and magnitudes of lattice distortion $\varepsilon$, dislocation density $\rho$, and damage parameters $\omega$ are increased with increasing numbers cycles of alternating bending. The character of changes can be described by the corresponding regression equations (7) - (9) and (11).

It is observed the anisotropy of the both elastic modulus and damage parameters, both in the original sheet processed according to the mode II and after alternating bending. The anisotropy of the elastic modulus reaches its maximum value after 3 cycles of the alternating bending. Anisotropy coefficients of damage parameters are maximal after 1 cycle of alternating bending. Anisotropy minimums of the elastic modulus and damage parameters are observed after 5 cycles of the alternating bending.

Changes in the values of crystalline domains sizes $D$, lattice distortion $\varepsilon$, dislocations density $\rho$, elastic modulus E, and damage parameters $\omega$ are mainly due to the crystallographic texture formed during thermomechanical processing and cycle's number of subsequent alternating bending of sheets. The corresponding regularities have been described by regression equations (14) - (19), as well as (21-26).

\section{ORCID IDs}

(D)Valentin Usov https://orcid.org/0000-0001-7855-5370, (D) Heinz-Günter Brokmeier https://orcid.org/0000-0002-8808-1313, (D) Nataliia Shkatulyak https://orcid.org/0000-0003-4905-001X, (DElena Savchuk https://orcid.org/0000-0002-4249-6505

\section{REFERENCES}

[1] Z. Yang, J.P. Li, J.X. Zhang, G.W. Lorimer, and J. Robson, 21(5) 313-326 (2008), https://doi.org/10.1016/S1006-7191(08)60054$\mathrm{X}$

[2] L. Ruihong, P. Fusheng, B. Jiang, D. Hanwu and Y. Qingshan, Materials Science \& Engineering A, 562, 33-38 (2013), http://dx.doi.org/10.1016/j.msea.2012.11.032

[3] K. Alaneme, and E. Okotete, Journal of Magnesium and Alloys, 5 (4), 460-475, (2017), https://doi.org/10.1016/j.jma.2017.11.001

[4] H. Hafekamp, M. Niemeyer, R. Bohem, U. Holzkamp, C. Jaschik and V. Kaese, Material Science Forum, 350-351, 31-42 (2000). https://doi.org/10.4028/www.scientific.net/MSF.350-351.31

[5] Methods of leveling sheet metal https://blog.arku.com/us/methods-of-leveling-sheet-metal/

[6] N. Shkatulyak, S. Smirnova, and V. Usov, Hindawi Publishing Corporation, International Journal of Metals, Article ID 349810,8 pages, (2015). http://dx.doi.org/10.1155/2015/349810.

[7] L.M. Kachanov, Основы механики разрушения [Fundamentals of fracture mechanics], (Nauka, Moscow, 1974 ), 312 p. https://lib-bkm.ru/13776 [in Russian].

[8] Y.N. Rabotnov, Избранные произведения. Проблемы механики деформируемого твердого тела [Selected works. Problems of the mechanics of a deformable solid], (Nauka, Moslow, 1991, 196 p.) [in Russian].

[9] J. Lemaitre, R. Desmorat, and M. Sauzay,. Eur. J. Mech. A, 19 (2), 187-208, (2000). https://www.sciencedirect.com/science/article/pii/S0997753800001613

[10] N.R. Hansen, and H. L. Schreyer, Int. J. Solid. Structures, 31 (3), 359-389, (1994). https://kopernio.com/viewer?doi=10.1016/00207683(94)90112-

0\&token=WzM3NTM2LCIxMC4xMDE2LzAwMjAtNzY4Myg5NCk5MDExMi0wIl0.IbXai4W6T9jPyaO_4p_S86QIzV8

[11] C.L Chow, and J. Wang, International Journal of Fracture, 33, (1) 3-16, (1987), https://link.springer.com/article/10.1007/BF00034895.

[12] M. Bobyr, O. Khalimon, and O. Bondarets, Journal of Mechanical Engineering NTUU «Kyiv Polytechnic Institute», 67, 5-13, (2013). http://nbuv.gov.ua/UJRN/VKPI_mash_2013_67_3

[13] V.V. Usov, and N.M. Shkatulyak, Russian Physics Journal, 47, (11), 1139-1146, https://www.researchgate.net/publication/226984093_Fractal_nature_of_the_dislocation_structure_of_lowalloyed_steel_after_controlled_rolling

[14] Technical Review ITC-ME/ATCP (2010). http://www.atcpndt.com/images/products/sonelastic/articles/RT03-ATCP.pdf.

[15] H.-G. Brokmeier, S. Yil, N. Park and J. Homeyer. Electron Resource, Solid State Phenomena105, 55-60, (2005), http://www.scientific.net/SSP.105.55 
[16] H.-G. Brokmeier, Sangbong Yi, Textures in Engineering Materials: From Fundamentals to Applications, in Neutrons and Synchrotron Radiation in Engineering Materials Science, (2017) pp.55-72, Wiley-VCH

[17] FIT2D: An introduction Overview. http:/www.esrf.eu/computing/scientific/FIT2D/FIT2D_INTRO/fit2d.html

[18] G. Williamson and W. Hall Acta metallurgica, 1(1), 22-31 (1953). http://www.xray.cz/xray/csca/kol2011/kurs/Dalsicteni/clanky/Williamson-ActaMet-1953-1-22-WH-Plot.pdf

[19] T. Ungár, and J. Gubicza, Ultrafine Grained Materials II, 595-604, (2013), https://core.ac.uk/download/pdf/11856593.pdf

[20] P.R. Morris, Journal of Applied Physics, 30, (4), 595-596, (1959), https://doi.org/10.1063/1.1702413

[21] C. Dragomir, and T. Unga'r, J. Appl. Cryst., 35, 556-564, (2002). https://doi.org/10.1107/s0021889802009536

[22] H.B. Huntington, Solid State Physics, 213-351, (1958). https://doi.org/10.1016/S0081-1947(08)60553-6

[23] N. Shkatulyak, V. Usov and S. Smirnova, International Journal of Advances in Materials Science and Engineering, 4(4), 1-11, (2015), https://www.researchgate.net/publication/283650995_Single_Crystal_Magnesium_Lithium_Alloy_Elastic_Constants

[24] A. Borbely, http://metal.elte.hu/anizc/.

[25] Gubicza, N.H. Nam, K. Mathis, and V.V. Stolyarov, Z. Kristallogr. Suppl., 23, 93-98, (2006), http://gubicza.web.elte.hu/publikaciok/epdic9_sajat.pdf

[26] J.J. Kearns, Journal of Nuclear Materials, 299(2), 171-174 (2001), https://doi.org/10.1016/S0022-3115(01)00686-9.

[27] V. Grytsyna, D. Malykhin, T. Yurkova et al. East Eur. J. Phys. 3, 38-45 (2019), https://doi.org/10.26565/2312-4334-2019-3-05.

[28] N.V. Ageev, A.A. Babareko and S.Ya. Betsofen, Izv. Ross. Akad. Nauk, Ser. Met. 1, 94-103 (1974).

\section{ВПЛИВ ВИДУ ДЕФОРМАЦІЇ НА МОДУЛЬ ЮНГА, ПАРАМЕТР ПОШКОДЖЕНОСТИ, ТЕКСТУРУ І СТРУКТУРУ СПЛАВА Mg - 5\% (ваг.) Li}

Валентин Усов ${ }^{a}$, Хайнц-Гюнтер Брокмейер ${ }^{\mathrm{b}, \mathrm{e}}$, Наталія Шкатуляк ${ }^{\mathrm{c}}$, Олена Савчук ${ }^{\mathrm{d}}$, Норберт Шелл

а*Південноукраӥнський національний педагогічний університет імені К. Д. Уиинського, кафедра технологічної і професійної освіти, вул. Старопортофранківська. 26, 65020, Одеса, Украӥна

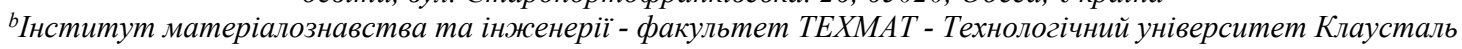
Agricolastrasse, 6, D-38678, Клаусталь-Целлерфельд, Німеччина

сПівденноукрайнський національний педагогічний університет імені К. Д. Ушинського, кафедра фізики вул. Старопортофранківська. 26, 65020, Одеса, Украӥна

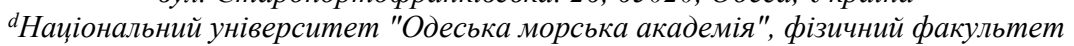
вул. Дідріхсона, 8, 65000, Одеса, Україна

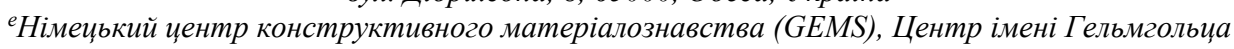
вул. Макса Планка, 1, D-21502 Гестхахт, Німеччина

Вивчено вплив деформації екструзією, прокаткою після екструзії (в поєднанні з відпалом і зміною напрямку прокатки) і подальшого знакозмінного вигину (ЗІ) з числом циклів $0,5,1,3$ i 5 на модуль пружності (Е), параметр накопичення пошкоджень (параметр пошкоджуваності $(\omega)$, кристалографічну текстуру і параметри субструктури бінарного сплаву Мg $5 \% \mathrm{Li}$ (ваг.). Параметр пошкоджуваності $(0 \leq \omega \leq 1)$, який інтерпретується як відносне зменшення ефективної несучої площі поперечного перерізу через накопичення пошкоджень, був знайдений зі зміни модуля пружності після різних вищезазначених типів деформації. При цьому ми використовували для порівняння моделі еквівалентної деформації та еквівалентної пружної енергії. Параметри субструктури (розміри кристалічних доменів D (області когерентного розсіювання, мікродеформації кристалічної гратки $\varepsilon$, щільність дислокацій $\rho$ ) оцінювалися шляхом аналізу фізичного розширення ліній дифракції жорсткого проникаючого рентгенівського синхротронного випромінювання на кристалічній гратці досліджуваного сплаву. Було виявлено, що після екструзії злитка сплаву при $350^{\circ} \mathrm{C}$ і подальшої прокатки в напрямку осі екструзії (напрямок прокатки НП) до товщини 4,5 мм в поєднанні з відпалом при $350^{\circ} \mathrm{C}$ після кожного проходу утворюється текстура. При такій текстурі вісь шестигранної призми відхиляється на $90^{\circ}$ від нормального напряму (НН) до поперечного напрямку (ПН). При цьому кристалографічні напрямки $\langle 11 \overline{2} 0\rangle$ i $\langle 10 \overline{1} 0\rangle$ збігаються з НП. Текстура, при якій вісь гексагональної призми відхиляється від НН до ПН на кути від 15 до $70^{\circ}$ (на відміну від текстури базисного типу чистого магнію), формується після подальшої прокатки досліджуваного сплаву до товщини 1 мм зі зміною НП після кожного проходу на $90^{\circ}$ в поєднанні з відпалом при $350^{\circ} \mathrm{C}$. Кристалографічні напрямки $\langle 21 \overline{3} 1\rangle$ збігаються з НП. Виявлена анізотропія вищевказаних характеристик. В результаті кореляційного і регресійного аналізу було встановлено, що анізотропія і значення $E$ і $D$ зменшуються, а значення $\varepsilon, \rho$ і $\omega$ збільшуються зі збільшенням числа циклів знакозмінного вигину. Показано, що зміни вищевказаних характеристик обумовлені, в основному, кристалографічною текстурою, сформованою в процесі термомеханічної обробки і подальшого знакозмінного вигину листів сплаву $\mathrm{Mg}-5 \% \mathrm{Li} \mathrm{(ваг.),} \mathrm{що}$ підтверджується даними кореляційного і регресійного аналізу.

КЛЮЧОВІ СЛОВА: екструзія, прокатка, знакозмінний вигин, текстура, анізотропія, модуль Юнга, параметр пошкоджуваності, субструктура.

\section{ВЛИЯНИЕ ВИДА ДЕФОРМАЦИИ НА МОДУЛЬ ЮНГА, ПАРАМЕТР ПОВРЕЖДЕННОСТИ,} ТЕКСТУРУ И СТРУКТУРУ СПЛАВА Mg - 5\% (вес.) Li

Валентин Усов ${ }^{a}$, Хайнц-Гюнтер Брокмейер ${ }^{b, e}$, Наталья Шкатуляк ${ }^{c}$, Елена Савчук ${ }^{d}$, Норберт Шелл

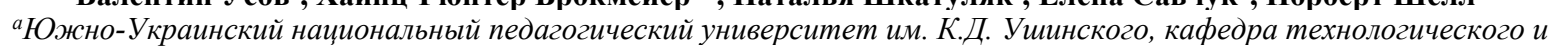
профессионального образования, ул. Старопортофранковская. 26, 65020, Одесса, Украина

${ }^{b}$ Институт материаловедения и инженерии - факультет ТЕХМАТ - Технологический университет Клаусталь, Agricolastrasse, 6, D-38678, Клаусталь-Целлерфельд, Германия

' Южно-Украинский национальный педагогический университет им. К. Д. Уиинского, физический факультет ул. Старопортофранковская. 26, 65020, Одесса, Украина

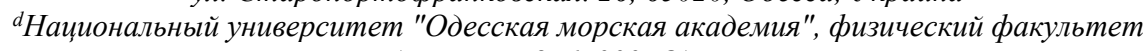
улииа Дидрихсона, 8, 65000, Одесса, Украина

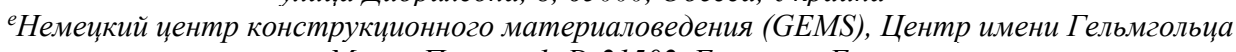
ул. Макса Планка, 1, D-21502, Гестахт, Германия 
Изучено влияние деформации экструзией, прокаткой после экструзии (в сочетании с отжигом и изменением направления прокатки) и последующего знакопеременного изгиба (ЗИ) с числом циклов $0,5,1,3$ и 5 на модуль упругости $(E)$, параметр накопления повреждений (параметр поврежденности $\omega$ ), кристаллографическую текстуру и параметры субструктуры бинарного сплава $\mathrm{Mg}-5 \% \mathrm{Li}$ (вес.). Параметр поврежденности $(0 \leq \omega \leq 1)$, который интерпретируется как относительное уменьшение эффективной несущей площади поперечного сечения из-за накопления повреждений, был найден по изменению модуля упругости после различных вышеупомянутых типов деформации. При этом мы использовали для сравнения модели эквивалентной деформации и эквивалентной упругой энергии. Параметры субструктуры (размеры кристаллических доменов $D$ (области когерентного рассеяния), микроискажения решетки $\varepsilon$, плотность дислокаций $\rho$ ) оценивались путем анализа физического уширения линий дифракции на кристаллической решетке исследуемого сплава проникающего жесткого рентгеновского синхротронного излучения. Было обнаружено, что после экструзии слитка сплава при $350^{\circ} \mathrm{C}$ и последующей прокатки в направлении оси экструзии (направление прокатки НП) до толщины 4,5 мм в сочетании с отжигом при $350^{\circ} \mathrm{C}$ после каждого прохода образуется текстура. При такой текстуре ось шестигранной призмы отклоняется на $90^{\circ}$ от нормального направления $(\mathrm{HH})$ к поперечному направлению $($ ПН). При этом кристаллографические направления $\langle 11 \overline{2} 0\rangle$ и $\langle 10 \overline{1} 0\rangle$ совпадают с НП. Текстура, при которой ось гексагональной призмы отклоняется от НН до ПН на углы от 15 до $70^{\circ}$ (в отличие от текстуры базисного типа чистого магния), формируется после дальнейшей прокатки исследуемого сплава до толщины 1 мм с изменение НП на $90^{\circ}$ в сочетании с отжигом при $350^{\circ} \mathrm{C}$ после каждого прохода. Кристаллографические направления $\langle 21 \overline{3} 1\rangle$ совпадают с НП. Обнаружена анизотропия вышеуказанных характеристик. В результате корреляционного и регрессионного анализа было установлено, что анизотропия и значения $\mathrm{E}$ и $\mathrm{D}$ уменьшаются, а значения $\varepsilon, \rho$ и $\omega$ увеличиваются с увеличением числа циклов чередующегося изгиба. Показано, что изменения вышеуказанных характеристик обусловлены, в основном, кристаллографической текстурой, сформированной в процессе термомеханической обработки и последующего знакопеременного изгиба листов сплава $\mathrm{Mg}$ - $5 \% \mathrm{Li}$ (вес.), что подтверждается данными корреляционного и регрессионного анализа.

КЛЮЧЕВЫЕ СЛОВА: экструзия, прокатка, знакопеременный изгиб, текстура, анизотропия, модуль Юнга, параметр поврежденности, субструктура 